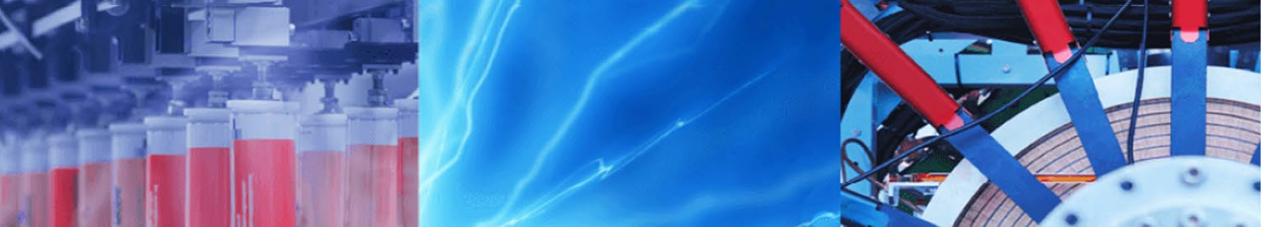

Research Article

\title{
Geochronology, genesis and landscape of Yanshanian granite in Guangzhou area, central Guangdong Province of China
}

\author{
Xiaofei Guo ${ }^{1,2} \cdot$ Yu Tian $^{3} \cdot$ Xiaobing Zhang ${ }^{4}$
}

(c) Springer Nature Switzerland AG 2019

\begin{abstract}
Based on field geological investigation and zircon U-Pb isotope dating of granites in Guangzhou, central Guangdong, the formation age, petrogenesis and weathering characteristics of granites are discussed. The LA-ICPMS zircon U-Pb ages of Huolushan and Liuqianshan granites in central Guangdong are 159.1 $\pm 3.5 \mathrm{Ma}$ and 156.2 $\pm 4.4 \mathrm{Ma}$, respectively. These granites show low crystallization temperature $\left(\sim 800^{\circ} \mathrm{C}\right)$ and negative low $\varepsilon_{\mathrm{Hf}}(\mathrm{t})$ values $(-9.4$ and -9.8$)$, with two-stage model ages of 1241-1666 Ma, indicating that they were derived from partial melting of the Proterozoic crust. According to the geological and geomorphological characteristics of the granite area in central Guangdong, it is considered that lithology is the material basis of the granite landscape. Structural factors such as joints and faults are important controlling factors. The climatic and hydrological conditions in the granite area also play an important role in the formation of granite landforms.
\end{abstract}

Keywords Guangzhou · Granite · Geochronology · Lu-Hf isotope · Geomorphologic landscape

\section{Introduction}

South China preserves evidence of large-scale magmatism and is known for extensive mineralization. They enjoy a high reputation both in terms of resource type and aesthetic value e.g., $[2,6,20,39]$. The mineralization of a large number of polymetallic deposits such as tungsten and tin is considered to be highly correlated with the Mesozoic granitic magmatism e.g., [12, 17, 25, 26, 37, 44]. At the same time, REE-rich granite regolith is a significant host for the ion-adsorption type Rare Earth Elements (REE) ore resources in South China [9]. After the formation of granite, as long as the overlying rock is stripped, a large area of granite rock mass is exposed [30]. When the granite is close to the ground or exposed, the protruding corners of the large rock gradually become smoother, forming a spherical-like weathering body [32]. The resulting spherical weathering of granite is a widely distributed geomorphic element, especially in humid granitic areas. Regarding the safety factor of its stability, the predecessors have performed analysis based on mechanical calculations and physical tilt tests [23]. Some scholars believe that the tectonic and lithological controls for granite geomorphology is very important. For example, long-term uplift and subsidence are often responsible for the spatial pattern of major landforms. Lithological differences appear to have a significant influence on landform development in the long-term, controlling the rates of various exogenous processes [22]. In tectonically quiet regions, the shape of the granite landscape is controlled by the erosion resistance of the rock. Erosion is highly dependent on the release of particles from weathered rock and a degree of dissolution [7]. The weathering of granite in ultra-arid and low-temperature environments is mainly controlled by oxidation,

$\triangle$ Xiaofei Guo, guoxiaofei351@hotmail.com | 'School of Resource and Environmental Engineering, Jiangxi University of Science and Technology, Ganzhou 341000, China. ${ }^{2}$ Jiangxi Key Laboratory of Mining Engineering, Jiangxi University of Science and Technology, Ganzhou 341000, China. ${ }^{3}$ State Key Laboratory of Mineralogy and Metallogeny, Guangzhou Institute of Geochemistry, Chinese Academy of Sciences, Guangzhou 510640, China. ${ }^{4}$ State Key Laboratory of Isotope Geochemistry, Guangzhou Institute of Geochemistry, Chinese Academy of Sciences, Guangzhou 510640, China. 
including veins formed by thermal expansion and contraction and oxide alterations inside the rock [13].

Among the granites located in many forest parks in Guangzhou area, central Guangdong Province of South China, the spherical weathering is a common geological phenomenon. Regarding the formation age and the genesis of these granites, the predecessors paid more attention to the migmatite-gneiss suite in the study area [38, 40]. However, previous studies less involved the granite rock mass and the common granite geomorphology. In this study, the author collects representative samples to discuss the diagenetic age and rock genesis, and investigates the granite characteristics to explore the role of granite in the formation of geological relics and the significance of tourism geology. In this way, people can receive a knowledge experience when they appreciate the magic of nature.

\section{Regional geology and petrology}

South China preserves the record of intense tectonic-magmatic activities with associated widely distributed granites in the Mesozoic, especially in the Nanling Range. The extensive granitic magmatism has generated a large number of Jurassic and Cretaceous granites. The exposed area exceeds more than $30,000 \mathrm{~km}^{2}$ and a small amount of Triassic granite with an exposed area of $3260 \mathrm{~km}^{2}$ in Nanling area and its neighboring areas (Fig. 1a; [45]). A large number of polymetallic ore deposits formed during the Mesozoic, especially tungsten and tin mineralization. They are related to the extensive Mesozoic magmatic activities e.g., $[3,14,21]$. Guangzhou area is located in the Southern China fold system. Influenced by the Caledonian, Indosinian, Yanshanian and Himalayan cycle, folds and fractures of different scales were developed within the range. Among them, the Northeast Guangcong fault and the East-West Shougouling fault are the most prominent [47]. The granites in the study area mainly include the complex granites formerly known as the Luogang rock mass (Fig. 1b; [38]).

The studied monzonitic granite (samples: GZ-2 and GZ-3) were collected from the Huolushan and Liupianshan in the western part of Luogang rock mass and the northeastern part of Guangzhou. They commonly show porphyritic texture and massive structure (Fig. 2a and b). The mineral assemblage is mainly composed of plagioclase, K-feldspar, quartz, biotite and muscovite. Myrmekite is common between plagioclase and K-feldspar (Fig. 2c and d).

\section{Analytical methods}

In this study, the LA-ICP-MS zircon U-Pb dating technique was used to determine the zircon $\mathrm{U}-\mathrm{Pb}$ age and in situ $\mathrm{Lu}-\mathrm{Hf}$ isotope of representative rock samples from the Huolushan and Liupianshan granites in Guangzhou area, central Guangdong Province of south China. Zircons were sorted from fresh samples by gravity separation, magnetic separation and other separation techniques. Under the binocular microscope, no cracks, no inclusions, transparent and clean zircon were selected and immobilized on glass panels with epoxy resin. Then they were polished. Subsequently, reflected light and transmitted light photomicrography and cathodoluminescence $(C L)$ image were performed to examine their internal structures. Zircon $\mathrm{U}-\mathrm{Pb}$ and $\mathrm{Lu}-\mathrm{Hf}$ isotope analysis were undertaken using Neptune multi-collector ICPMS equipped with $193 \mathrm{~nm}$ ArF excimer laser in Guangzhou Institute of Geochemistry (GIG), Chinese Academy of Sciences (CAS).The specific analysis procedure is described in the literature [41, 42]. The zircon $\mathrm{U}-\mathrm{Pb}$ isotope ratio was calculated using theTEMORA as external standard. Fractional calibration and calculation were performed using ICPMS DataCal (8.4) [18]. Data processing was performed using the Ludwig 2001 SQUID 1.02 and ISOPLOT programs [19].

\section{Results}

\subsection{Zircon $\mathrm{U}-\mathrm{Pb}$ age}

The zircon $\mathrm{U}-\mathrm{Pb}$ isotopic composition is shown in Table 1. The typical zircon $\mathrm{CL}$ image and age concordia plot are shown in Figs. 3 and 4.

The zircon grains in the sample GZ-2 display the shape of idiomorphic crystal with oscillatory zoning. A total of sixteen spots were selected for the zircon $\mathrm{U}-\mathrm{Pb}$ isotope analysis. Two of the spots (GZ-2-03 and GZ-2-15) may be zircons from the wall rock captured by the upwelling magma, and their ${ }^{206} \mathrm{~Pb} /{ }^{238} \mathrm{U}$ ages are $247.3 \pm 8.8 \mathrm{Ma}$ and $220.2 \pm 7.2 \mathrm{Ma}$, respectively. Eight of the remaining spots were distributed over the concordant curve and the weighted average of ${ }^{206} \mathrm{~Pb} /{ }^{238} \mathrm{U}$ was $159.1 \pm 3.5 \mathrm{Ma}$ $(M S W D=0.89)$. These analysis spots show Th/U ratios greater than 0.1 . Therefore, the crystallization age of this sample was $159.1 \pm 3.5 \mathrm{Ma}$.

The zircon grains separated in the sample GZ-3 exhibited strong oscillatory zonations. The ${ }^{206} \mathrm{~Pb} /{ }^{238} \mathrm{U}$ age of the GZ-3-14 is $795.2 \pm 23.1 \mathrm{Ma}$, which may be zircon captured from the wall rock during the magma 


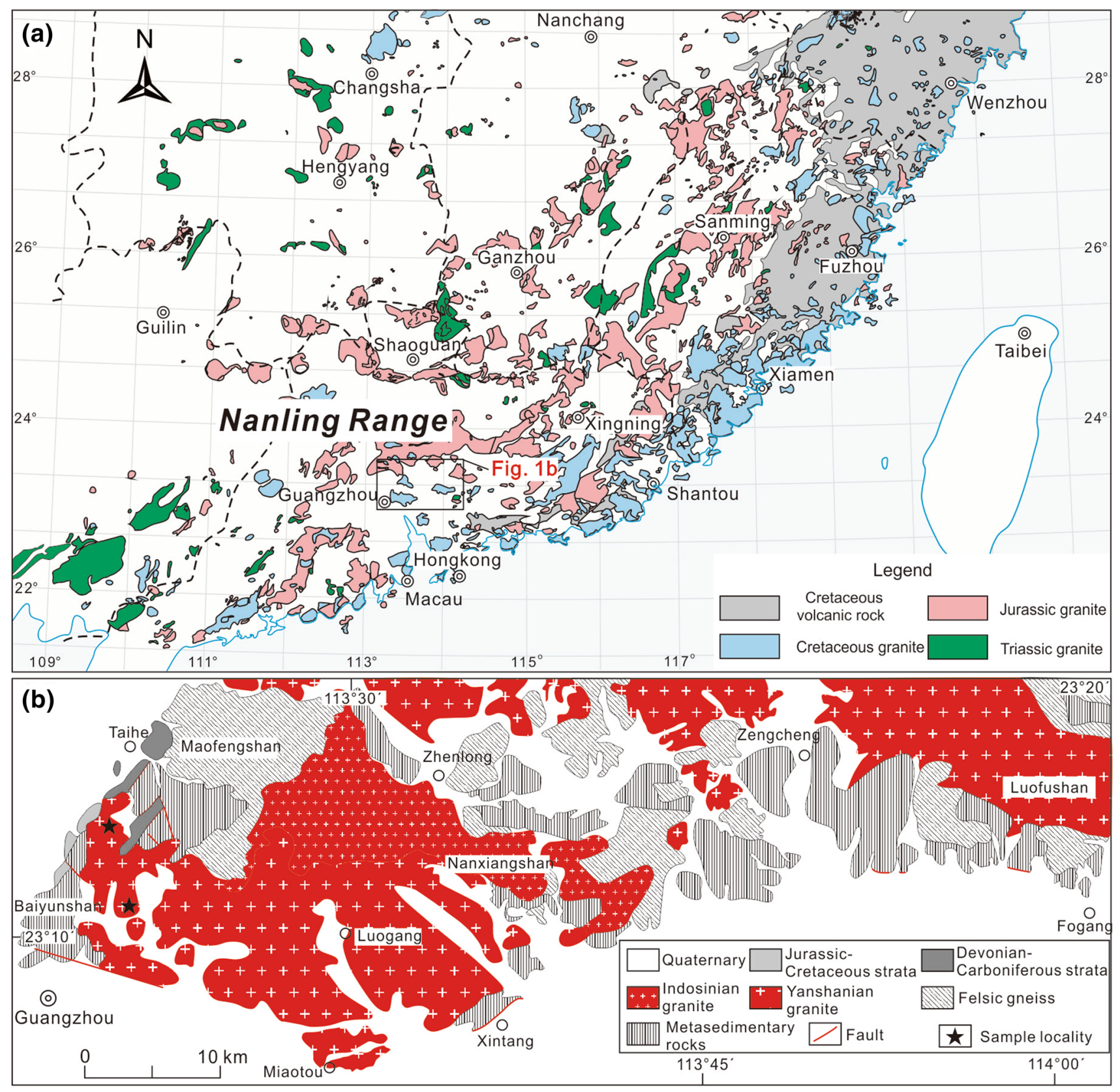

Fig. 1 a Regional distribution of the Mesozoic igneous rocks in the southeastern SCB (modified after [29] and b Geological map of the eastern and northeastern parts in Guangzhou area, central Guangdong Province of China (modified after [38]

emplacement. The remaining fourteen spots show $T h / U$ ratios of $0.10-0.93$ and yield a weighted average of ${ }^{206} \mathrm{~Pb} /{ }^{238} \mathrm{U}$ age of $156.2 \pm 4.4 \mathrm{Ma}$. Combining the chronological results with the $C L$ image analysis, we believe that 156.2 \pm 4.4 Ma represents the crystallization age of the sample.

\subsection{Zircon Hf isotopes}

The zircon in situ Lu-Hf isotopic results are listed in Table 2.
In-situ Lu-Hf isotope analysis of eight zircon grains from the Huolushan granite (GZ-2) shows that the calculated $\varepsilon_{\mathrm{Hf}}(\mathrm{t})$ is -13.0 to -5.3 , with an average of -9.4 , and the two-stage model age $\mathrm{T}_{\mathrm{DM} 2}$ ranges from 1241 to $1618 \mathrm{Ma}$, according to $\mathrm{t}=159.1 \mathrm{Ma}$, as shown in Figs. $5 \mathrm{a}$ and $6 a$.

Fourteen zircon grains were carried out by in situ Lu-Hf isotope analysis on Liupianshan granite (GZ-3), with ${ }^{176} \mathrm{Hf}$ $/{ }^{177} \mathrm{Hf}=0.282282 \sim 0.282470$. According to the formation age of $\mathrm{t}=156.2 \mathrm{Ma}, \varepsilon_{\mathrm{Hf}}(\mathrm{t})=-14.0$ to -7.3 , average -9.8 , the 

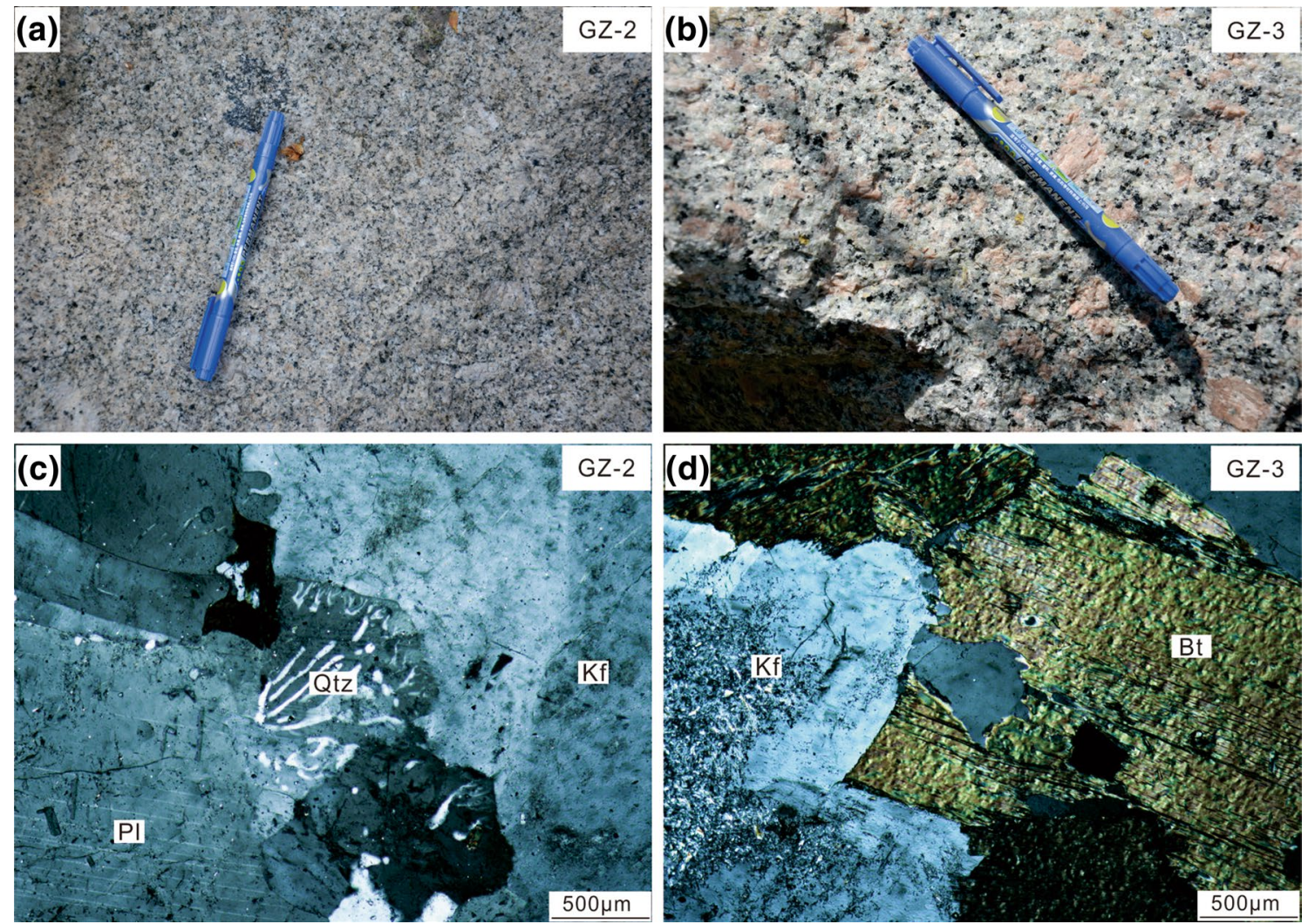

Fig. 2 The outcrop photographs (a-b) and corresponding photomicrographs (c-d) of the granites collected from Huolushan and Liupianshan in Guangzhou area, central Guangdong Province of China. Abbreviations: Pl, plagioclase; Kf, K-feldspar; Qtz, quartz; Bt, biotite

two-stage model age $\mathrm{T}_{\mathrm{DM} 2}$ is between $1339 \sim 1666 \mathrm{Ma}$, as shown in Figs. $5 \mathrm{~b}$ and $6 \mathrm{a}$.

\section{Discussion}

\subsection{Formation age and petrogenesis}

The Huolushan and Liupianshan granites are distributed in the the eastern part of Guangzhou, formerly known as the Luogang rock mass $[4,16,46]$. For the Luogang rock mass, some scholars have identified the Indosinian I-type granites formed in the Triassic [5], while others have identified the Jurassic crustal anatectic Yanshanian granites [4]. This shows that the Luogang rock mass is a complex rock mass formed by multi-stage sub-magmatic invasion. For Yanshanian granites in Guangzhou, the age data obtained by early scholars mainly used $\mathrm{Rb}-\mathrm{Sr}$ isotope dating, and the age range was concentrated at 203-155 Ma [4]. Since the $\mathrm{Rb}-\mathrm{Sr}$ dating is usually reset or affected by late tectonic thermal events, these ages and their errors are in a larger range.

In this paper, zircon $\mathrm{U}-\mathrm{Pb}$ dating was carried out on the samples of the Huolushan and Liupianshan granites from the west side of the Luogang rock mass. The results show that the crystallization age of Huolushan granite (GZ-2) is $159.1 \pm 3.5 \mathrm{Ma}$, and the crystallization age of Liupianshan granite (GZ-3) is $156.2 \pm 4.4 \mathrm{Ma}$. This shows that they were formed in the late Jurassic. This period is one of the most significant periods of magmatic activity in the geological history of South China, and the number of granites and their corresponding metallogenic events is numerous. The Fogang rock mass located in the northeastern part of the Luogang rock mass is the largest complex rock foundation exposed in the Nanling area. Analogously, Li et al. [15] yielded consistent ages ranging from $159 \pm 3 \mathrm{Ma}$ to $165 \pm 2 \mathrm{Ma}$ by SHRIMP U-Pb zircon analyses for four samples from the Fogang Batholith. Huang et al. [11] studied the granite rock mass distributed in the southwest coastal area of Guangdong Province, and obtained the embedding age of 166-159 Ma. Zhang et al. [43] collected 12 granitic intrusions from coastal to inland areas in eastern Guangdong Province, and obtained their zircon $\mathrm{U}-\mathrm{Pb}$ ages of 165-154 Ma. These age data indicate that the Jurassic granite is widely distributed in the south of China from the coast to the inland.

According to the analysis below, we proposed that the Huolushan and Liupianshan granite were likely produced

\section{SN Applied Sciences}


Table $1 \mathrm{U}$-Pb isotopic ratios and ages of zircons from the granites collected from Guangzhou area in central Guangdong Province, China

\begin{tabular}{|c|c|c|c|c|c|c|c|c|c|c|c|c|c|}
\hline \multicolumn{2}{|l|}{ Content } & \multirow[t]{2}{*}{ Th/U } & \multicolumn{6}{|c|}{ Isotopic ratios } & \multicolumn{4}{|l|}{ Age(Ma) } & \multirow{2}{*}{$\begin{array}{l}\text { Concord- } \\
\text { ance (\%) }\end{array}$} \\
\hline Th (ppm) & $\mathrm{U}(\mathrm{ppm})$ & & ${ }^{207} \mathrm{~Pb} /{ }^{206} \mathrm{~Pb}$ & $1 \sigma$ & ${ }^{207} \mathrm{~Pb} /{ }^{235} \mathrm{U}$ & $1 \sigma$ & ${ }^{206} \mathrm{~Pb} /{ }^{238} \mathrm{U}$ & $1 \sigma$ & ${ }^{207} \mathrm{~Pb} /{ }^{235} \mathrm{U}$ & $1 \sigma$ & ${ }^{206} \mathrm{~Pb} /{ }^{238} \mathrm{U}$ & 10 & \\
\hline 2490 & 2338 & 1.07 & 0.04970 & 0.00230 & 0.17694 & 0.00832 & 0.02590 & 0.00086 & 165.4 & 7.2 & 164.8 & 5.4 & 99 \\
\hline 798 & 1624 & 0.49 & 0.05035 & 0.00234 & 0.16953 & 0.00794 & 0.02425 & 0.00078 & 159.0 & 6.9 & 154.4 & 4.9 & 97 \\
\hline 621 & 1501 & 0.41 & 0.05131 & 0.00257 & 0.27657 & 0.01481 & 0.03912 & 0.00141 & 247.9 & 11.8 & 247.3 & 8.8 & 99 \\
\hline 1266 & 2868 & 0.44 & 0.04744 & 0.00207 & 0.15785 & 0.00688 & 0.02408 & 0.00076 & 148.8 & 6.0 & 153.4 & 4.8 & 96 \\
\hline 939 & 2487 & 0.38 & 0.05043 & 0.00230 & 0.17319 & 0.00807 & 0.02485 & 0.00082 & 162.2 & 7.0 & 158.2 & 5.1 & 97 \\
\hline 1217 & 3230 & 0.38 & 0.04916 & 0.00211 & 0.16884 & 0.00730 & 0.02485 & 0.00080 & 158.4 & 6.3 & 158.2 & 5.0 & 99 \\
\hline 320 & 602 & 0.53 & 0.07520 & 0.00499 & 0.26815 & 0.01822 & 0.02560 & 0.00085 & 241.2 & 14.6 & 163.0 & 5.3 & 61 \\
\hline 507 & 878 & 0.58 & 0.04814 & 0.00289 & 0.16852 & 0.00998 & 0.02537 & 0.00082 & 158.1 & 8.7 & 161.5 & 5.2 & 97 \\
\hline 919 & 531 & 1.73 & 0.07094 & 0.00454 & 0.21097 & 0.01404 & 0.02197 & 0.00082 & 194.4 & 11.8 & 140.1 & 5.1 & 67 \\
\hline 1277 & 937 & 1.36 & 0.05530 & 0.00331 & 0.16661 & 0.00971 & 0.02196 & 0.00074 & 156.5 & 8.4 & 140.0 & 4.7 & 88 \\
\hline 968 & 773 & 1.25 & 0.05543 & 0.00286 & 0.23138 & 0.01197 & 0.03021 & 0.00099 & 211.3 & 9.9 & 191.8 & 6.2 & 90 \\
\hline 575 & 1333 & 0.43 & 0.04737 & 0.00245 & 0.17193 & 0.00883 & 0.02627 & 0.00084 & 161.1 & 7.6 & 167.2 & 5.3 & 96 \\
\hline 2684 & 2759 & 0.97 & 0.05057 & 0.00228 & 0.14163 & 0.00645 & 0.02024 & 0.00065 & 134.5 & 5.7 & 129.2 & 4.1 & 95 \\
\hline 816 & 1200 & 0.68 & 0.06851 & 0.00417 & 0.24398 & 0.01521 & 0.02548 & 0.00084 & 221.7 & 12.4 & 162.2 & 5.3 & 69 \\
\hline 785 & 721 & 1.09 & 0.05141 & 0.00273 & 0.24560 & 0.01300 & 0.03474 & 0.00115 & 223.0 & 10.6 & 220.2 & 7.2 & 98 \\
\hline 933 & 1496 & 0.62 & 0.04974 & 0.00226 & 0.16968 & 0.00778 & 0.02468 & 0.00079 & 159.1 & 6.7 & 157.2 & 4.9 & 98 \\
\hline 1043 & 10791 & 0.10 & 0.05064 & 0.00207 & 0.16754 & 0.00665 & 0.02393 & 0.00075 & 157.3 & 5.8 & 152.5 & 4.7 & 96 \\
\hline 686 & 919 & 0.75 & 0.05399 & 0.00299 & 0.15804 & 0.00822 & 0.02199 & 0.00075 & 149.0 & 7.2 & 140.2 & 4.7 & 93 \\
\hline 897 & 1973 & 0.45 & 0.04291 & 0.00201 & 0.15276 & 0.00725 & 0.02569 & 0.00082 & 144.3 & 6.4 & 163.5 & 5.2 & 87 \\
\hline 723 & 992 & 0.73 & 0.04930 & 0.00248 & 0.17845 & 0.00906 & 0.02630 & 0.00086 & 166.7 & 7.8 & 167.3 & 5.4 & 99 \\
\hline 1103 & 3557 & 0.31 & 0.04657 & 0.00200 & 0.16681 & 0.00726 & 0.02590 & 0.00084 & 156.6 & 6.3 & 164.8 & 5.3 & 94 \\
\hline 1025 & 2371 & 0.43 & 0.05320 & 0.00280 & 0.17901 & 0.00947 & 0.02426 & 0.00078 & 167.2 & 8.2 & 154.5 & 4.9 & 92 \\
\hline 774 & 1878 & 0.41 & 0.04702 & 0.00231 & 0.16593 & 0.00808 & 0.02557 & 0.00082 & 155.9 & 7.0 & 162.8 & 5.1 & 95 \\
\hline 524 & 1343 & 0.39 & 0.04781 & 0.00229 & 0.16863 & 0.00820 & 0.02539 & 0.00083 & 158.2 & 7.1 & 161.6 & 5.2 & 97 \\
\hline 698 & 752 & 0.93 & 0.05722 & 0.00344 & 0.19714 & 0.01169 & 0.02496 & 0.00081 & 182.7 & 9.9 & 158.9 & 5.1 & 86 \\
\hline 1066 & 3024 & 0.35 & 0.05034 & 0.00213 & 0.17663 & 0.00797 & 0.02520 & 0.00085 & 165.2 & 6.9 & 160.5 & 5.3 & 97 \\
\hline 395 & 773 & 0.51 & 0.05207 & 0.00276 & 0.17800 & 0.00943 & 0.02476 & 0.00081 & 166.3 & 8.1 & 157.7 & 5.1 & 94 \\
\hline 513 & 1384 & 0.37 & 0.04933 & 0.00238 & 0.15629 & 0.00735 & 0.02295 & 0.00074 & 147.4 & 6.5 & 146.3 & 4.6 & 99 \\
\hline 489 & 2621 & 0.19 & 0.07068 & 0.00250 & 1.29184 & 0.04571 & 0.13128 & 0.00406 & 842.1 & 20.3 & 795.2 & 23.1 & 94 \\
\hline 449 & 919 & 0.49 & 0.05554 & 0.00286 & 0.18476 & 0.00968 & 0.02392 & 0.00077 & 172.1 & 8.3 & 152.4 & 4.9 & 87 \\
\hline 1168 & 2506 & 0.47 & 0.05343 & 0.00224 & 0.17763 & 0.00731 & 0.02404 & 0.00076 & 166.0 & 6.3 & 153.2 & 4.8 & 91 \\
\hline
\end{tabular}
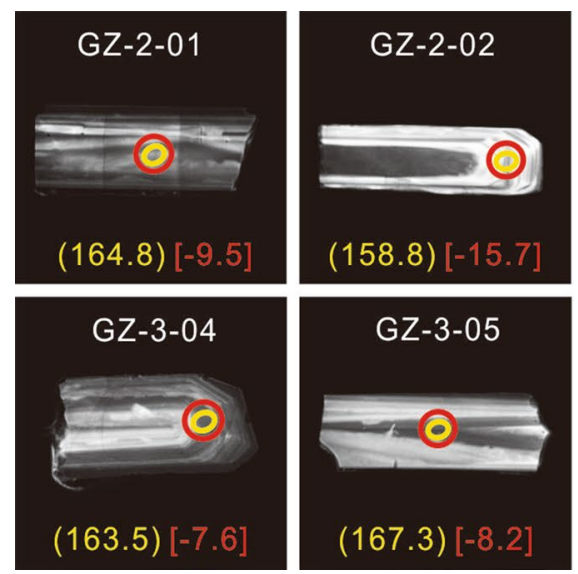
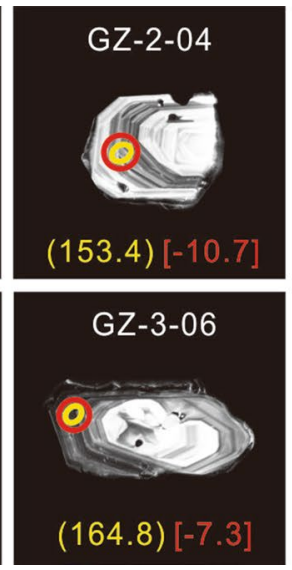
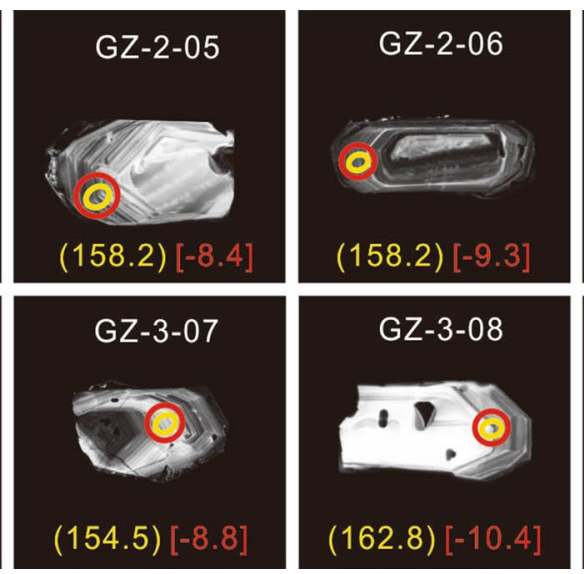

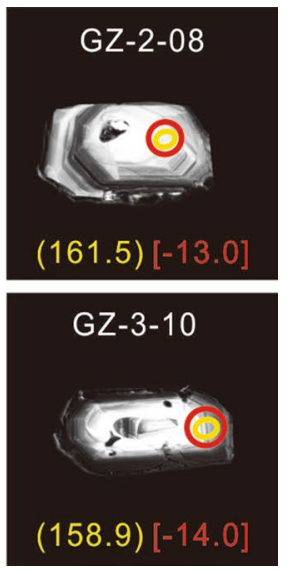

Fig. $3 \mathrm{CL}$ images of representative zircons from Huolushan and Liupianshan granites. The small ellipses indicate the LA-ICP-MS analytical spots for $\mathrm{U}-\mathrm{Pb}$ isotopes and large circles denote the LA-ICP-
MS analytical spots for Lu-Hf isotopes. Numbers near the analytical spots are the $\mathrm{U}-\mathrm{Pb}$ ages (within parentheses) and $\varepsilon_{\mathrm{Hf}}(\mathrm{t})$ values [within square brackets] 

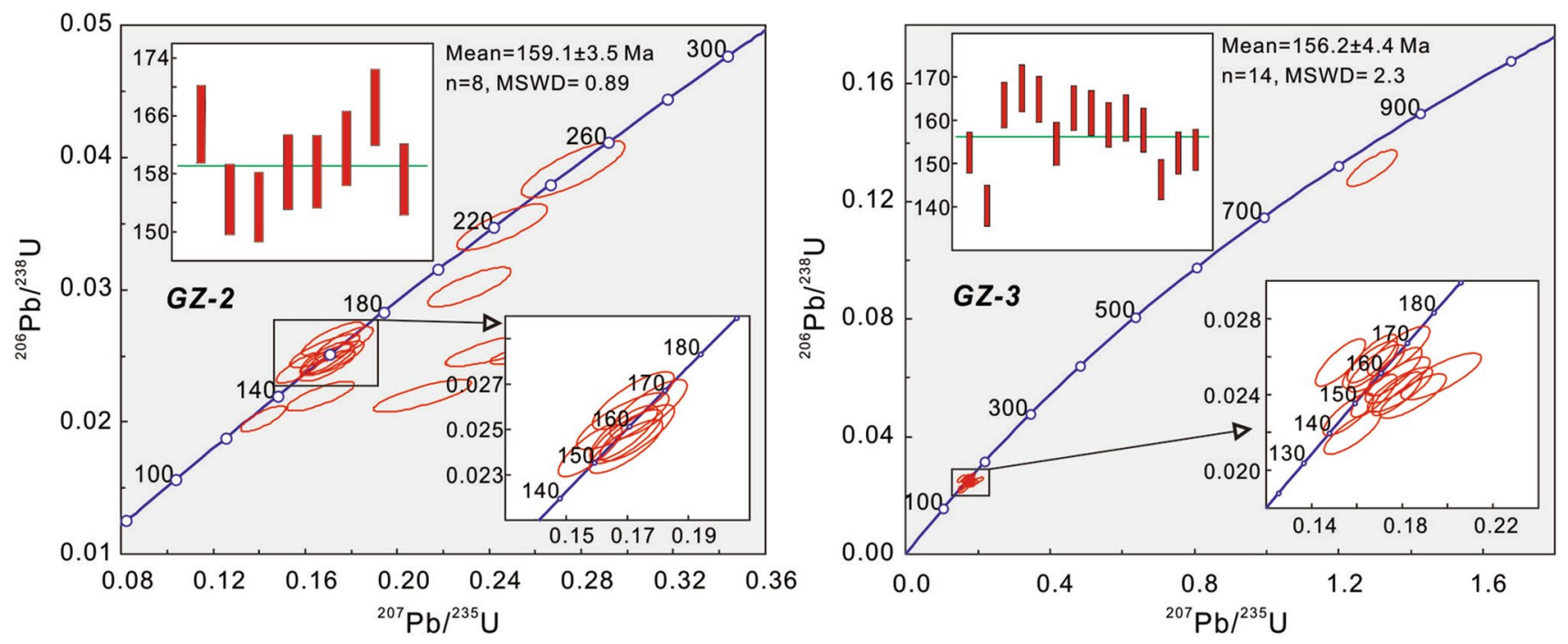

Fig. 4 LA-ICPMS Zircon U-Pb concordia age plots for the granites collected from Huolushan and Liupianshan in Guangzhou area, central Guangdong Province of China

by partial melting of Proterozoic ancient crust. (1) In-situ zircon Lu-Hf isotope analysis results in this study show that the granites from the Huolushan and Liupianshan in Guangzhou area have relatively homogeneous zircon $\mathrm{Hf}$ isotopic compositions with lower $\varepsilon_{\mathrm{Hf}}(\mathrm{t})$ values ranging from -14.0 to -5.3 and two-stage model ages of 1666-1241 Ma, similar to those of basement rocks in eastern Cathaysia Block (Fig. 6a), which represents by highly evolved Proterozoic crust [27], implying that they could have originated from basement rocks in the Cathaysia Block. (2) Geochemical data show that the Huolushan and Liupianshan granite has aluminum supersaturation and initial value of ${ }^{87} \mathrm{Sr} /{ }^{86} \mathrm{Sr}>0.7100$, which indicates that they belong to continental remelted granite [4]. (3) Crystallization temperature of zircons from the the Huolushan and Liupianshan granite is calculated using Ti-in zircon thermometer of Watson et al. [33]. The calculation results show that the average crystallization temperature of zircons is $\sim 800^{\circ} \mathrm{C}$ (Fig. 6 b), similar to those of S-type granite generating from ancient crust, but different from those of typical A-type granite with high crystallization temperature $[24,28]$ and adakitic rock deriving from mafic lower crust or juvenile arc crust [1].

\subsection{Geomorphological landscape and controlling factors}

Many granitic rock eggs were seen in the area of the Huolushan and Liupianshan granite in Guangzhou, central Guangdong Province of China (Fig. 7). The large and stacking of granitic rock eggs were related with both spherical weathering and water scouring. After the formation of granite body, the pressure relaxes when exposed near the ground or rising. Under the weathering action of physical, chemical and biological factors, spherical layered rock blocks are peeled off along the joint plane. The relics of rock blocks are dominated by quartz, feldspar and other minerals [30, 31]. Specifically, the spherical weathering of granite in Guangzhou area is mainly controlled by the following factors.

Firstly, lithology is the material basis of the granite landscape. Lithological differences revealed in grain size, mineralogical composition and water impermeability. The massive and dense crystal structure allows the weathering to proceed only on the surface of the rock, from the exterior to the inner layer. The impermeability allows the rainfall to runoff on the surface of the rock, enhancing water erosion of the rock. The effect is that when the weathering shell on the rock mass is denuded, the flowing water is infiltrated along the joints, and the huge granite body is separated to become the initial state of the huge stone egg topography. With the deepening of weathering, the angular edges of the massive rock mass fall off and the square-shaped rock mass changes to a smooth shape [39]. In addition, different minerals in the rock mass have different weathering resistance. The common rock-forming minerals in the Huolushan and Liupianshan granite mainly include quartz, feldspar, and mica. In general, the weathering resistance of quartz and feldspar is stronger than that of mica. This is why most of the spherical weathering bodies have quartz and potassium feldspar residual spots in the study area (Fig. $7 a$ and b). Some scholars agree that the truly outstanding landscape and silica are consistent with the high-potassium granite bodies [8]. The rock mass 


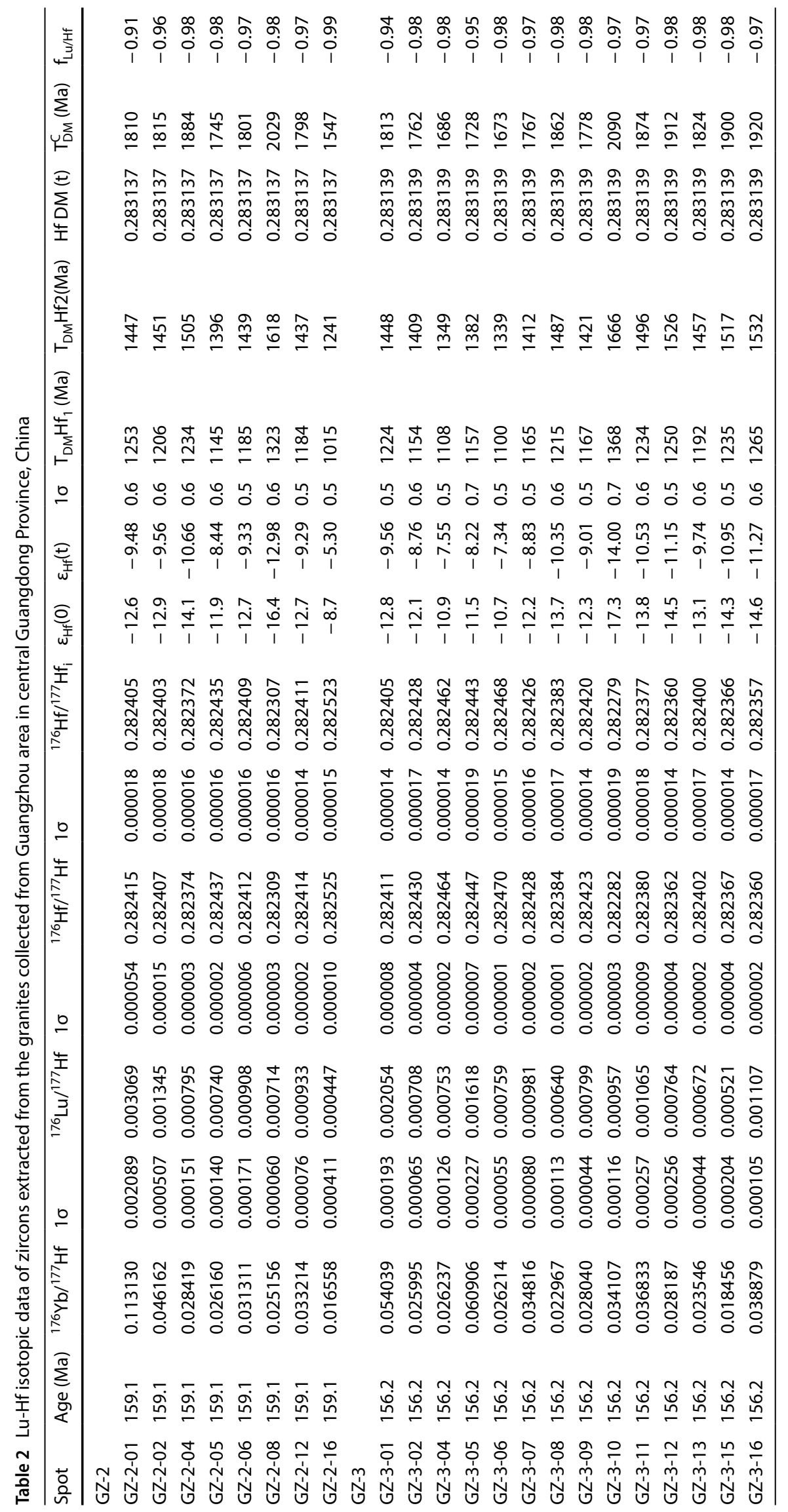



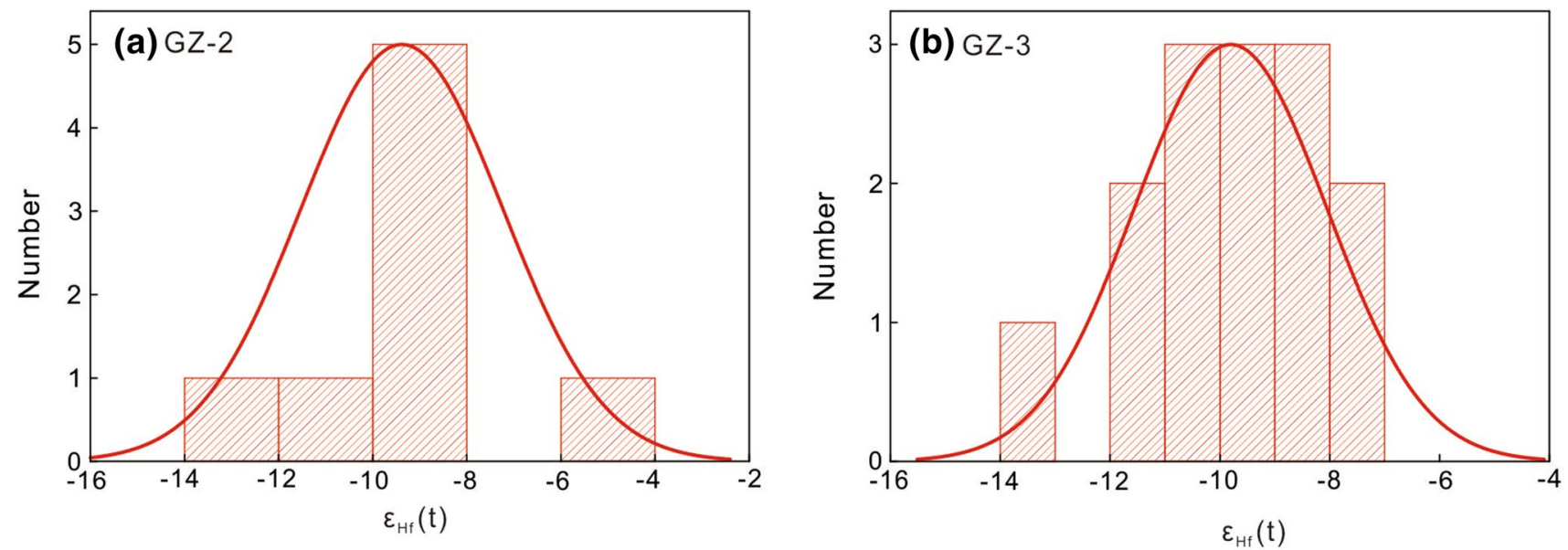

Fig. 5 Histograms of $\varepsilon_{\mathrm{Hf}}(\mathrm{t})$ values of zircons from the granites collected from Huolushan and Liupianshan in Guangzhou area, central Guangdong Province of China

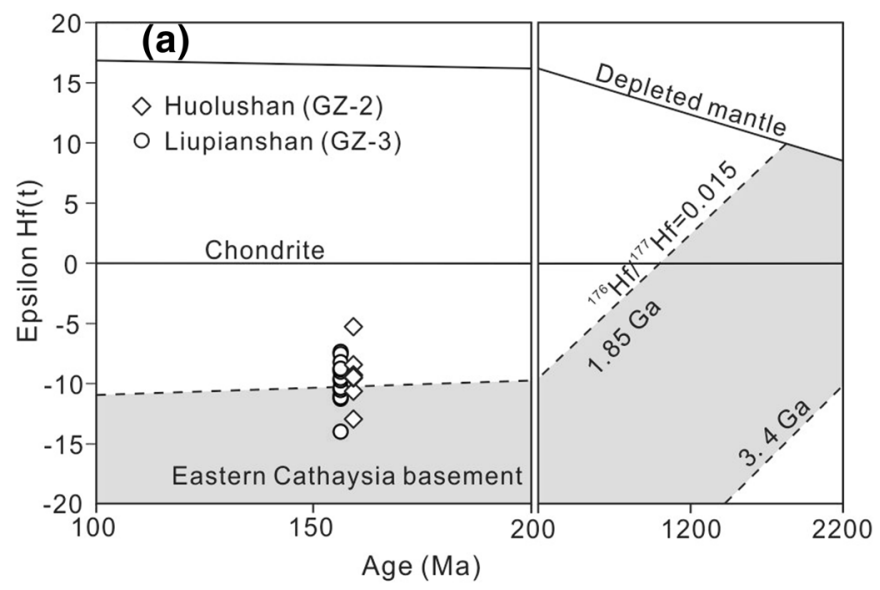

Fig. 6 Diagrams of zircon $\varepsilon_{\mathrm{Hf}}(\mathrm{t})$ values versus crystallization ages (a) and Ti-in-zircon crystallisation temperatures versus crystallization ages (b) for the granites collected from Huolushan and Liupianshan

has better integrity and stronger weathering resistance, and it seems to be more conducive to the shaping of the landscape with ornamental value.

Secondly, structural factors such as joints and faults are important controlling factors for granite landform. In fact, granite is plutonic igneous rock formed by the condensation of magma in the deep underground. The reason why we have seen so many granite landforms must have experienced structural uplift to near-surface or full exposure. The terrain ups and downs caused by the active lifting or faulting can form a landform-type layout. As a result, the development of granite joints is very obvious, which provides a geological basis for the spherical weathering of granite. The fault structures are well developed in the study area, and the deformation stages of the Shougouling fault zone are from Late Triassic to Quaternary $[36,47]$. In

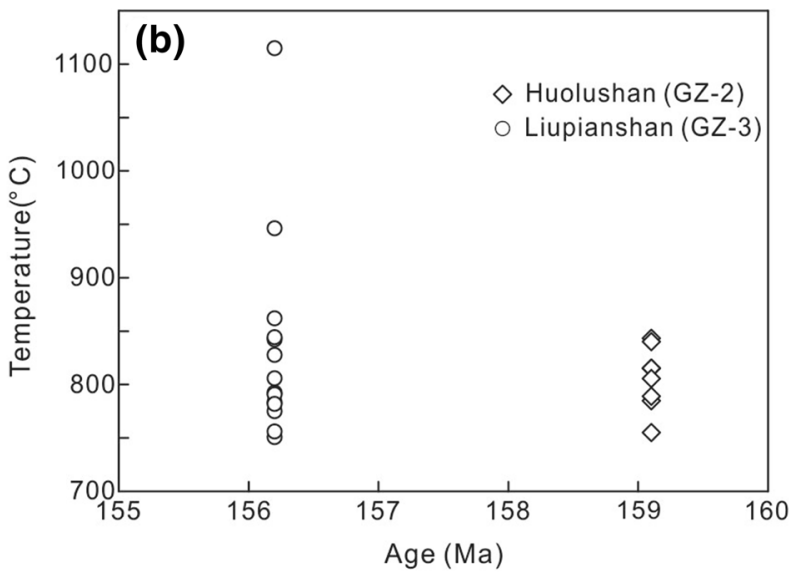

in Guangzhou area, central Guangdong Province of China. The Hf isotope evolution for the crustal basement of the eastern Cathaysia Block is indicated by the shaded region $[10,35]$

the later geological history, many rhombic jointed tectonic systems destroyed the robustness and impermeability of the granite itself. Groundwater and chemical weathering and biological weathering can be penetrated vertically or horizontally [39]. This also coincides with the joint and brittle crack observed in the field. (Figure $7 \mathrm{~d}$ and e). On the granite hills with thick weathering crusts, strong cut valleys are often formed. At the top of the granite mountainous terrain, the surface weathered soils are washed away, and are scattered into large stone eggs by spherical peeling.

Finally, the climatic and hydrological conditions in the granite area also play an important role in the formation of granite landforms. It can be highly weathered under hot and humid conditions, because most of the chemical reactions occur at high temperatures. In the dry and cold 
Fig. 7 Characteristics of Huolushan and Liupianshan granites in Guangzhou area, central Guangdong Province of China. a The bright part of high weathering degree granite are quartz particles with strong resistance to weathering; b Huge particle feldspar porphyroclasts; c Rounded shape of the egg-shaped stone; $\mathbf{d}$ Joints of the developments in spherical weathering body e Brittle crack of spherical weathering body; $\mathbf{f}$ Layer peeling in a regular round of spherical weathering body
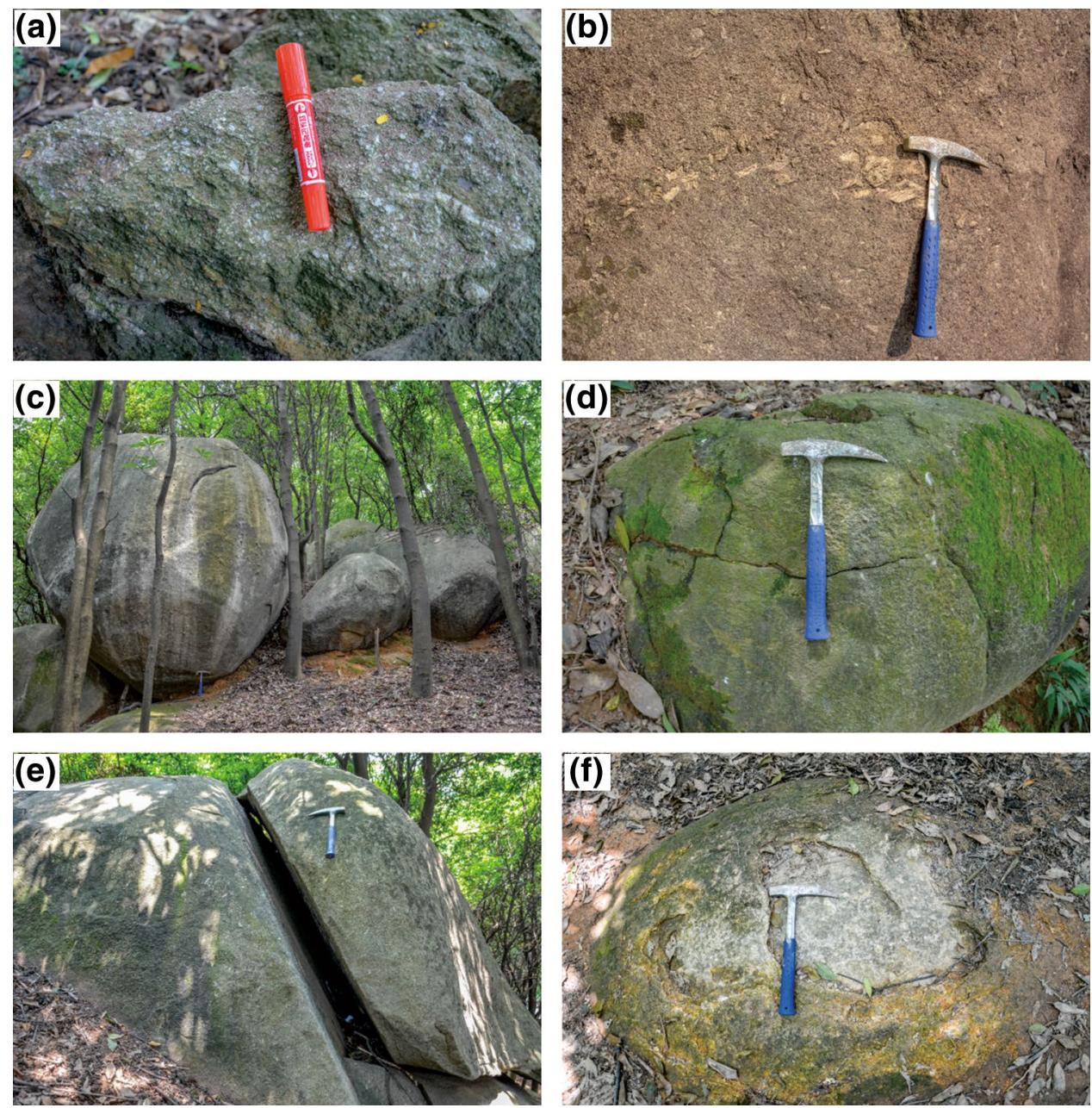

climate, physical weathering mainly occurs and breaks into small fragments [34]. Guangzhou area is located on the subtropical coast. The Tropic of Cancer passes through the south-central region. It is a maritime subtropical monsoon climate with sufficient light and heat, simultaneous water and heat and abundant rainfall. In addition, Guangzhou area is often hit by typhoons. The granite is washed by rain, and the fine-grained minerals on the surface are washed away by a large amount. This has evolved into a scouring groove for a long time, which provides favorable external environmental conditions for the formation of globular weathering.

\section{Conclusions}

Through the LA-ICP-MS zircon $\mathrm{U}-\mathrm{Pb}$ dating technology, the formation ages of the Huolushan and Liupianshan monzonitic granites in Guangzhou area, central Guangdong Province of China were 159.1 $\pm 3.5 \mathrm{Ma}$ and
$156.2 \pm 4.4 \mathrm{Ma}$, respectively. They correspond to the large-scale magmatism of the Late Jurassic. The average values of zircon $\varepsilon_{\mathrm{Hf}}(\mathrm{t})$ are -9.4 and -9.8 , and the twostage model ages are 1241-1618 Ma and 1339-1666 Ma, respectively. They were likely produced by partial melting of Proterozoic ancient crust. Regarding the spherical weathering characteristics of granite in the study area, they are controlled by many factors. Lithology is the material basis of the granite landscape. Structural factors such as joints and faults are important controlling factors. The climatic and hydrological conditions in the granite area also play an important role in the formation of granite landforms.

Acknowledgements We would express sincere thanks to Hongxia Yu and Le Zhang for $t$ heir help with fieldwork and indoor analytical measurements.

Funding This study was funded by the Science and Technology Project of Jiangxi Province Department of Education (GJJ170539) and the Doctoral Scientific Research Foundation of Jiangxi University of Science and Technology (jxxjbs17068). 


\section{Compliance with ethical standards}

Conflict of interest The author declares that there is no confict of interests regarding the publication of this paper.

\section{References}

1. Cai YF, Wang YJ, Cawood PA, Zhang YZ, Zhang AM (2015) Neoproterozoic crustal growth of the Southern Yangtze Block: geochemical and zircon U-Pb geochronological and Lu-Hf isotopic evidence of Neoproterozoic diorite from the Ailaoshan zone. Precambr Res 266:137-149

2. An-ze C (2007) Some problems of granite geomorphological landscapes. Geol Rev 53(s1):1-8 (in Chinese with English abstract)

3. Chen J, Wang RC, Zhu JC, Lu JJ, Ma DS (2013) Multiple-aged granitoids and related tungsten-tin mineralization in the Nanling Range, South China. Sci China Earth Sci 56(12):2045-2055

4. Chen JC (1991) Geological characteristics of granitoids in Guangzhou. Guangdong Geol 6(1):1-16 (in Chinese with English abstract)

5. Chen SQ, Zhuang WM, Huang YY (2000) Geological and geochemical characteristics of Luogang granitoid of Guangzhou. Guangdong Geol 15(3):26-32 (in Chinese with English abstract)

6. Cui ZJ, Chen YX, Yang XY (2009) Granite landform characteristics, distribution and evolution patterns in Huangshan Mt. Chin Sci Bull 54(23):4487-4499

7. Eggleton RA (2017) Mineralogy maketh mountains: granitic landscapes shaped by dissolution. Geomorphology 285:363-373

8. Fan X (2015) Wonderful psychedelic, discovering the granite landscape of the Altai Mountains in Xinjiang. Chin Natl Geogr 5:54-65 (in Chinese)

9. Fu W, Li XT, Feng YY, Feng M, Peng Z, Yu HX, Lin H (2019) Chemical weathering of S-type granite and formation of Rare Earth Element (REE)-rich regolith in South China: Critical control of lithology. Chem Geol 520:33-51

10. He ZY, Xu XS, Niu Y (2010) Petrogenesis and tectonic significance of a Mesozoic granite-syenite-gabbro association from inland South China. Lithos 119(3):621-641

11. Huang HQ, Li XH, Li ZX, Li WX (2013) Intraplate crustal remelting as the genesis of Jurassic high-K granites in the coastal region of the Guangdong Province, SE China. J Asian Earth Sci 74(s1):280-302

12. Jiang $H$, Jiang SY, Li WQ, Zhao KD, Peng NJ (2018) Highly fractionated Jurassic I-type granites and related tungsten mineralization in the Shirenzhang deposit, northern Guangdong, South China: Evidence from cassiterite and zircon $\mathrm{U}-\mathrm{Pb}$ ages, geochemistry and $\mathrm{Sr}-\mathrm{Nd}-\mathrm{Pb}-\mathrm{Hf}$ isotopes. Lithos 312-313:186-203

13. Kanamaru T, Suganuma $Y$, Oiwane $H$, Miura $H$, Miura $M$, Okuno J, Hayakawa $\mathrm{H}$ (2018) The weathering of granitic rocks in a hyper-arid and hypothermal environment: a case study from the Sør-Rondane Mountains, East Antarctica. Geomorphology 317:62-74

14. Li H, Palinkaš LA, Watanabe $K$, Xi XS (2018) Petrogenesis of Jurassic A-type granites associated with $\mathrm{Cu}-\mathrm{Mo}$ and $\mathrm{W}$-Sn deposits in the central Nanling region, South China: Relation to mantle upwelling and intra-continental extension. Ore Geol Rev 92:449-462

15. Li XH, Li ZX, Li WX, Liu Y, Yuan C, Wei GJ, Qi CS (2007) U-Pb zircon, geochemical and $\mathrm{Sr}-\mathrm{Nd}-\mathrm{Hf}$ isotopic constraints on age and origin of Jurassic I- and A-type granites from central
Guangdong, SE China: a major igneous event in response to foundering of a subducted flat-slab? Lithos 96(1):186-204

16. Liu JX, Qiu RS, Wu JT, Zheng XB, Liao ST, Liu HD (2002) The inner tectonic characteristics and the emplacement mechanism of Luogang batholith in Guangzhou. Guangdong Geol 17(3):8-14 (in Chinese with English abstract)

17. Liu P, Mao JW, Santosh M, Bao ZA, Zeng XJ, Jia LH (2018) Geochronology and petrogenesis of the Early Cretaceous A-type granite from the Feie'shan W-Sn deposit in the eastern Guangdong Province, SE China: implications for W-Sn mineralization and geodynamic setting. Lithos 300:330-347

18. Liu YS, Gao S, Hu ZC, Gao CG, Zong KQ, Wang DB (2010) Continental and oceanic crust recycling-induced melt-peridotite interactions in the Trans-North China Orogen: $\mathrm{U}-\mathrm{Pb}$ dating, $\mathrm{Hf}$ isotopes and trace elements in zircons from mantle xenoliths. J Petrol 51(1-2):537-571

19. Ludwig KR (2003) User's manual for Isoplot/Ex, version 3.0, a geochronological toolkit for Microsoft Excel. Berkeley Geochronology Center, CA, special publication, no. 4

20. Lv Y, Zheng LH, Men WH, Li YZ, Xu YL (2014) Genesis and classification of granite landscapes: A case study of the Huashan Mountains in Shanxi Province. Geol Explor 50(1):18-27 (in Chinese with English abstract)

21. Mao JW, Cheng YB, Chen MH, Pirajno F (2013) Major types and time-space distribution of Mesozoic ore deposits in South China and their geodynamic settings. Miner Depos 48(3):267-294

22. Migoń P, Vieira G (2014) Granite geomorphology and its geological controls, Serra da Estrela, Portugal. Geomorphology 226:1-14

23. Pérez-Rey l, Alejano LR, Riquelme A, González-deSantos L (2019) Failure mechanisms and stability analyses of granitic boulders focusing a case study in Galicia (Spain). Int J Rock Mech Min Sci 119:58-71

24. Price JD, Hogan JP, Gilbert MC, London D, Morgan GBV (1999) Experimental study of titanite-fluorite equilibria in the A-type Mount Scott Granite: implications for assessing F contents of felsic magma. Geology 27(10):190-202

25. Qiu ZW, Li SS, Yan QH, Wang H, Wei XP, Li P, Wang LM, Bu A (2017) Late Jurassic Sn metallogeny in eastern Guangdong, SE China coast: evidence from geochronology, geochemistry and $\mathrm{Sr}$ $\mathrm{Nd}-\mathrm{Hf}-\mathrm{S}$ isotopes of the Dadaoshan Sn deposit. Ore Geol Rev 83:63-83

26. Qiu ZW, Yan QH, Li SS, Wang $H$, Tong $L X$, Zhang RQ, Wei XP, Li P, Wang LM, Bu A, Yan LM (2017) Highly fractionated early cretaceous I-type granites and related Sn polymetallic mineralization in the Jinkeng deposit, eastern Guangdong, SE China: constraints from geochronology, geochemistry, andHf isotopes. Ore Geol Rev 88:718-738

27. Shen WZ, Wang DZ, Liu CS (1995) Isotope geochemical characteristics and material sources of tin-bearing porphyry in South China. Acta Geol Sin 69:349-359 (in Chinese with English abstract)

28. Skjerlie KP, Johnston AD (1993) Fluid-absent melting behavior of an F-rich tonalitic gneiss at mid-crustal pressures: implications for the generation of anorogenic granites. J Petrol 34(4):785-815

29. Sun $T$ (2006) A new map showing the distribution of granites in South China and its explanatory notes. Geol Bull China 25(3):332-335 (in Chinese with English abstract)

30. Twidale CR (1986) Granite landform evolution: factors and implications. Geol Rev 75(3):769-779

31. Vasile M, Vespremeanu-Stroe A (2016) Thermal weathering of granite spheroidal boulders in a dry-temperate climate, Northern Dobrogea, Romania. Earth Surf Process Landf 42(2):259-271

32. Wang H, Liu CY, Chen ZB (2011) Granite spherical weathering features and related engineering geological problems in the 
southeast area of Fujian province. J Eng Geol 19(4):564-569 (in Chinese with English abstract)

33. Watson EB, Wark DA, Thomas JB (2006) Crystallization thermometers for zircon and rutile. Contrib Miner Petrol 151(4):413-433

34. Wei HR, Zhang ZC (2007) Types of granite landscapes and discussions on their formation processes. Geol Rev 53(s1):147-159 (in Chinese with English abstract)

35. Xu XS, O'Reilly SY, Griffin WL, Wang XL, Pearson NJ, He ZY (2007) The crust of Cathaysia: age, assembly and reworking of two terranes. Precambr Res 158(1-2):51-78

36. Xu YX, Zhuang WM (2000) ${ }^{40} \mathrm{Ar}^{39} \mathrm{Ar}$ isotopic age of the Shougouling fault in Guangzhou area and its geological significance. Guangdong Geol 15(3):56-59 (in Chinese with English abstract)

37. Yan $\mathrm{QH}$, Wang H, Qiu ZW, Wei XP, Li P, Dong R, Zhang XY, Zhou KL (2018) Origin of Early Cretaceous A-type granite and related Sn mineralization in the Sanjiaowo deposit, eastern Guangdong, SE China and its tectonic implication. Ore Geol Rev 93:60-80

38. Yang DS, Li XH, Li WX, Liang XQ, Long WG, Xiong XL (2010) U-Pb and $40 \mathrm{Ar}-39 \mathrm{Ar}$ geochronology of the Baiyunshan gneiss (central Guangdong, south China): constraints on the timing of early Palaeozoic and Mesozoic tectonothermal events in the Wuyun (Wuyi-Yunkai) Orogen. Geol Mag 147(4):481-496

39. Yang YC, Yin ZS (2007) Marine erosional granite landforms on Pingtan Island-With a discussion on the series study of granite landforms and its innovation. Geol Rev 53(s1):125-131 (in Chinese with English abstract)

40. Yu PP, Zhang YZ, Zhou YZ, Weinberg RF, Zheng Y, Yang WB (2019) Melt evolution of crustal anatexis recorded by the Early Paleozoic Baiyunshan migmatite-granite suite in South China. Lithos 332-333:83-98

41. Yuan HL, Gao S, Liu XM, Li HM, Günther D, Wu FY (2004) Accurate $\mathrm{U}-\mathrm{Pb}$ age and trace element determinations of zircon by laser ablation-inductively coupled plasma-mass spectrometry. Geostand Geoanal Res 28(3):353-370

42. Zhang L, Ren ZY, Nichols ARL, Zhang YH, Zhang Y, Qian SP, Liu JQ (2014) Lead isotope analysis of melt inclusions by LA-MC-ICPMS. J Anal At Spectrom 29(8):1393-1405

43. Zhang Y, Yang JH, Sun JF, Zhang JH, Chen JY, Li XH (2015) Petrogenesis of Jurassic fractionated I-type granites in Southeast China: Constraints from whole-rock geochemical and zircon $\mathrm{U}-\mathrm{Pb}$ and $\mathrm{Hf}-\mathrm{O}$ isotopes. J Asian Earth Sci 111:268-283

44. Zheng W, Mao JW, Zhao HJ, Zhao CS, Yu XF (2017) Two Late Cretaceous A-type granites related to the Yingwuling W-Sn polymetallic mineralization in Guangdong province, South China: implications for petrogenesis, geodynamic setting, and mineralization. Lithos 274-275:106-122

45. Zhou XM, Shen WZ, Shu LS, Niu YL (2006) Petrogenesis of Mesozoic granitoids and volcanic rocks in South China: a response to tectonic evolution. Episodes 29(1):26-33

46. Zhuang WM, Chen SQ, Xu YX, Huang YY (2000) Tectonic assemblages features and orogenic-deep-seated process of Mesozoic igneous rocks in the central Guangdong area. Guangdong Geol 15(3):40-44 (in Chinese with English abstract)

47. Zou HP, Qiu YX, Zhuang WM, Shao RS (2001) Determination of deformation stages of the Shougouling fault zone in the Guangzhou area. Reg Geol China 20(1):67-72 (in Chinese with English abstract)

Publisher's Note Springer Nature remains neutral with regard to jurisdictional claims in published maps and institutional affiliations. 